
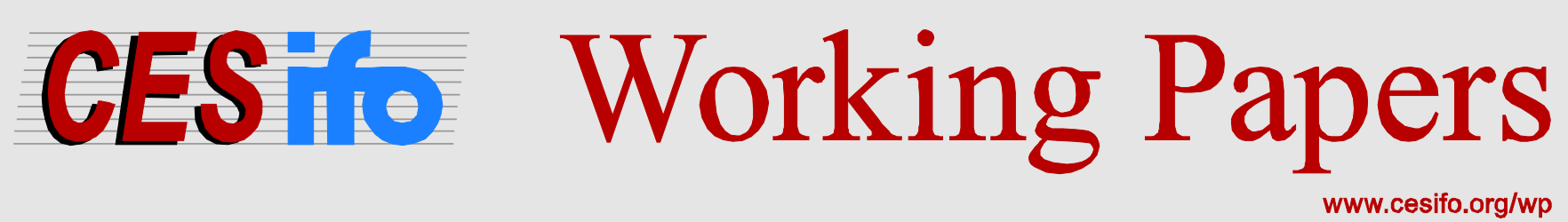

\title{
Private Debt and GDP: A Short-Run Perspective
}

\author{
Gianluca Cafiso
}

\author{
CESIFO WORKING PAPER NO. 6201 \\ CATEgory 6: Fiscal POLICY, MACROECONOMICS AND GROWTH \\ NOVEMBER 2016
}

An electronic version of the paper may be downloaded

- from the SSRN website:

- from the RePEc website:

- from the CESifo website: wWw.SSRN.com

Www.RePEc.org

www.CESifo-group.org/wp

\section{CESifo}




\title{
Private Debt and GDP: A Short-Run Perspective
}

\begin{abstract}
Mainstream economic research regards private debt as a determinant of GDP growth in the longrun. Levine (2005) surveys in details this branch of literature and explains the channels by which debt fuels growth. In this paper we switch the focus from the long to the short-run and study whether private debt has a significant impact on GDP growth in the short-run too. Our aim is to understand whether policy measures aimed to reduce the cost of private debt may favor a quick increase of the economic activity.
\end{abstract}

JEL-Codes: O110, O160, O510, O520, E440.

Keywords: private debt, GDP, short-run, VAR.

\author{
Gianluca Cafiso \\ University of Catania \\ Corso Italia 55 \\ Italy - 95129 Catania \\ gcafiso@unict.it \\ www.sites.google.com/site/giancafiso
}

October 2016

An initial version of this paper was drafted during my visiting research stay at the Graduate Institute (Geneva-Switzerland). I thank the Graduate Institute for this opportunity. 


\section{Contents}

1 Introduction $\quad 1$

2 Data 23

3 Analysis 1

3.1 Inference on the Estimation Output . . . . . . . . . . . . . . . . . . . 10

3.2 Discussion of the results . . . . . . . . . . . . . . . . . . . . . . . . 13

4 Conclusions $r$

$\begin{array}{ll}\text { References } & 15\end{array}$

$\begin{array}{lr}\text { Appendix A. Tables and Figures } & 17\end{array}$

$\begin{array}{lr}\text { Appendix B. VAR estimation output } & 19\end{array}$ 


\section{Introduction}

The steep rise of private debt has been a distinguishing feature of many western economies for the last four decades. Generally speaking, indebtedness, both public and private, has gone pace to pace with economic growth: All data show a simultaneous growth of private debt, public debt and GDP in many countries. The interplay between public and private debt has been recently studied by Jordà et al. $(2015,2014) .{ }^{1}$ In this work we focus on private debt.

The contemporaneous evolution of private debt and GDP has naturally led to investigate the causal relationship between them. There is a very large group of works which study causality between private debt and GDP by applying different techniques to different data-sets. Among the others, we highlight Rajan \& Zingales (1998), Levine et al. (2000), Christopoulos \& Tsionas (2004), Kar et al. (2011) and Puente-Ajovín \& Sanso-Navarro (2015) for the diversity of the approaches used. On the whole, conflicting results emerge (Ang 2008), but majority consensus tends to favor causality from private debt to growth. In an early, but comprehensive survey of this branch of literature, Levine (2005) explains in details the channels by which private debt should feed growth.

Once causality from private debt to GDP growth was taken for granted, more recent research has focused on other aspects of their relationship and it has provided further insights. Among the others, we highlight Arcand et al. (2015) who discuss and show that the relationship between the two is more complex than linear. Indeed, through across-countries analyses, they find that private debt above a certain threshold undermines growth or it is associated with less economic growth. This is in line with the non-linear effects found for public debt (Eberhardt \& Presbitero 2015).

This branch of literature considers private debt as a proxy of the financial depth of the economy. Then, the general result about the positive effect of private debt on growth has been regarded as the propelling effect of a well-developed financial system on economic growth. Of course, this has had direct normative implications. Indeed, this result has represented a stimulus to foster financial liberalization measures at the international level, measures often required by international organizations

\footnotetext{
${ }^{1}$ In these two contributions, the authors provide evidence in favor of a larger effect of private debt on the likelihood of a financial crisis by considering historical data.
} 
as the condition for financial support. ${ }^{2}$

Recent research on this topic has also considered the components of private debt separately in order to check whether a different effect emerges across different components. The paper by Puente-Ajovín \& Sanso-Navarro (2015) explicitly disentangles private non-financial debt into its two main components: households \& non-profit debt and non-financial corporations debt. This is in line with the contributions by Cecchetti and co-authors (Cecchetti et al. 2011a,b). Puente-Ajovín \& Sanso-Navarro (2015) spot Granger-causality particularly from households \& non-profit debt. ${ }^{3}$

The bulk of works on the relationship between private debt (meant as a proxy of financial depth) and GDP growth take a long-run perspective. The effect of year t-1 debt on the following 5-year GDP growth $(t+5 / t)$ is usually the object of the analysis; however, there have been interesting exceptions to this approach (Arestis et al. 2001). Differently, the objective of our research is to study the shortrun effect of private debt on GDP. Indeed, we are interested to understand whether private debt can stimulate economic activity quickly, and not just in the long-run. Quarterly data are functional to such a short-run focus.

Our interest on the short-run derives from policy interventions which ease the conditions on private debt quickly. ${ }^{4}$ Such interventions have often had the purpose to stimulate Aggregate Demand rapidly through its Consumption (Cloyne et al. 2016) and Investment components in order to foster economic activity (Papademos 2003, Blanchard et al. 2010, Mishkin 2011); these have often represented the policy reaction to an economic slowdown or an adverse shock. From this perspective, we aim to check whether or not those interventions have been effective.

Towards this end, unlike previous analyses on the long-run effect, we favor a country-by-country approach. Indeed, we believe that a country-by-country analysis can unveil significant differences about the effect of private debt on GDP, differences which are more likely in the short-run. We consider

\footnotetext{
${ }^{2}$ For an insight in this topic, among the others, see Rodrik (2006) and Estevadeordal \& Taylor (2013). More recently, however, the risks of liberalization have been also acknowledged, see IMF (2012).

${ }^{3}$ More in details, they study Granger-causality between debt and GDP growth in 16 OECD countries by applying a SUR-based approach on yearly data from 1980 to 2009.

${ }^{4}$ As regards the conditions on private debt, we mean the conditions at which financing is provided to the private nonfinancial sector. We have in mind mainly the interest rate on that debt. As known, market rates respond to the monetary policy rate set by the Central Bank when transmission works fine (ECB 2011). The Central Bank might therefore reduce the monetary-policy interest rate with intent to push downwards market rates to expand credit to the private sector in order to foster economic activity. However, it is not just an interest rate decrease to ease the provision of debt to the private sector. Indeed, even the creation of new lending facilities or the softening of collateral requirements may have the same effect.
} 
five countries: France, Italy, Germany, the United Kingdom, the United States. The first three are Euro Area countries expected to have more similar economies (at least over the last fifteen years), the UK is an EU country with a much developed financial system, the US is a benchmark in international comparisons across developed countries.

Our analytical strategy consists in calculating the GDP response to a positive private-debt shock, where private non-financial debt is considered through its two main components separately: i- Households \& Non-Profit Debt (HNPd), ii- Non-Financial Corporations Debt (NFCd). This recalls what done recently by Lof \& Malinen (2014) for public debt. If private-debt had a positive effect on GDP, we would expect to find a positive cumulative impact on GDP growth by some date after the shock. Given the motivation behind our research, to differentiate between HNPd and NFCd is relevant. The varying cost of debt affects differently different groups of private agents (Sufi 2015). Indeed, theoretically, an increase in households \& non-profit debt should act more quickly on GDP than an increase in nonfinancial corporation debt. The latter is more likely used for investment projects, which need more time to cause consumption of investment goods to rise.

To summarize, we underline that our research departs from the current literature in three important aspects. First, we focus on the short-run effect of private debt on GDP. Second, we consider the different components of the private debt aggregate. Third, we develop a country-by-country analysis. Consequently, we believe that our research complements those focused on long-run growth. Our results are therefore not intended neither to confute nor to support those. On the whole, they show that households \& non-profit debt is more effective as a stimulus to economic activity in the short run.

The paper is structured as follows. Section 2 describes the data-set used. Section 3 includes the analysis and its results. We draw the conclusions in section 4.

\section{Data}

A short-run analysis requires quarterly data. Quarterly data turn out to be convenient because they allow to increase a lot the number of time observations within the sample. Private debt data are usually available from the eighties up to the year before the current one, consequently, we can exploit a sample 
of about 145 observations per country. ${ }^{5}$ We can therefore afford to apply time series techniques country by country. As mentioned, we study five countries: France, Italy, Germany, the United Kingdom and the United States over the 1980q1-2015q3 period.

We use the private debt data made available by the Bank of International Settlements. ${ }^{6}$ These are quarterly data for private non-financial debt, to wit, the amount of bank lending granted to the private non-financial sector of the economy. Private Non-Financial debt (PNFd) is studied through its two main components: 1- Households \& Non-Profit debt (HNPd), 2- Non-Financial Corporations debt (NFCd). We extract private debt at market value in National Currency. All debt figures are originally in nominal terms, but we deflate them using the country-specific Consumers Price index (from OECD). ${ }^{7}$

Real GDP quarterly data for the same group of countries are extracted from the OECD database. Also the 3-moth Money-Market Rate (MMR) is used in the following analysis, this is extracted from Thomson Reuters.

To assess the different amounts of private debt across the countries under analysis, we plot it in GDP terms in Figure 1. In Germany, the UK and the USA, the amount of HNPd is comparable to NFCd. Differently, in France and Italy, HNPd is much smaller than NFCd. On the whole, the evolution is quite similar in all the countries considered. In all countries but France, the amount of HNPd and NFCd has decreased (Germany, the UK, the US) or has remained constant (Italy) after the Global Financial Crisis in 2008/09.

Many analyses normalize debt figures using the GDP and then consider the effect of normalized debt on GDP. We believe that this procedure might induce co-movement in the two series and condition somehow the results. We believe a normalization with respect to population to be more sound, we therefore use the variables in per-capita terms in our analysis. ${ }^{8}$ From here on, in the following Tables and Figures, the variable GDP is real GDP per-capita, PNFd is the Private Non-Financial Debt aggreagate in real per-capita terms, HNPd is the Households \& Non-Profit debt component in real per-capita terms, NFCd is the Non-Financial Corporations debt component in real per-capita terms.

\footnotetext{
${ }^{5}$ For some countries like the USA, a longer time span is available.

${ }^{6}$ Long series on total credit to the private non-financial sector (www.bis.org/statistics).

${ }^{7}$ We opt for national currency data since we develop a country-by-country analysis and consequently there is no need to have all the values in the same currency. At the same time, this avoids using data that might be somehow altered by the exchange rate conversion.

${ }^{8}$ Annual population data are extracted from the OECD database. To match the quarterly debt and GDP data, annual population figures are interpolated (cubic-spline) to quarterly values.
} 
Figure 1: Debt Levels wrt GDP

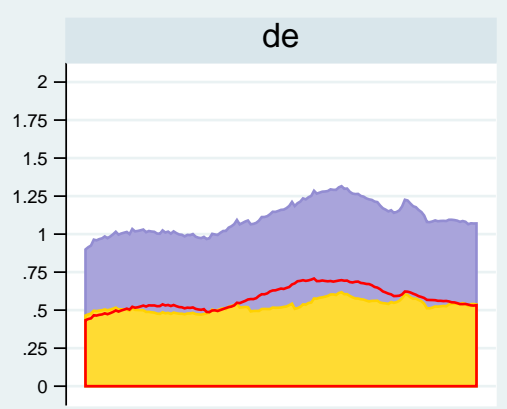

it

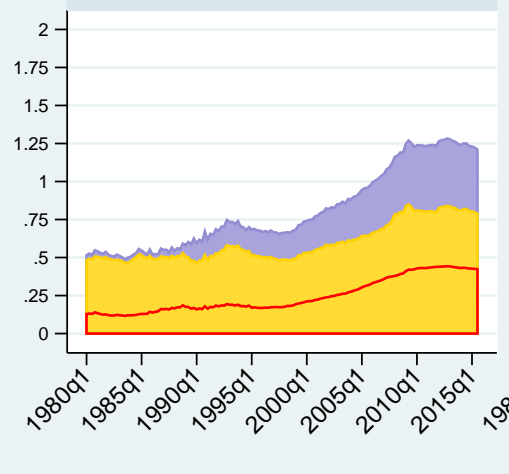

PNFd wrt GDP $\mathrm{fr}$

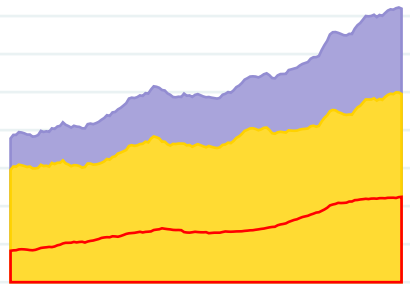

uk

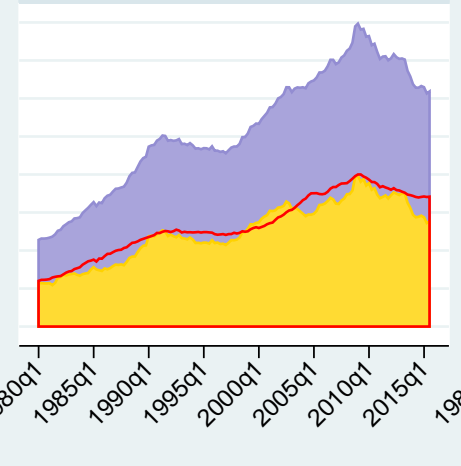

NFCd wrt GDP us

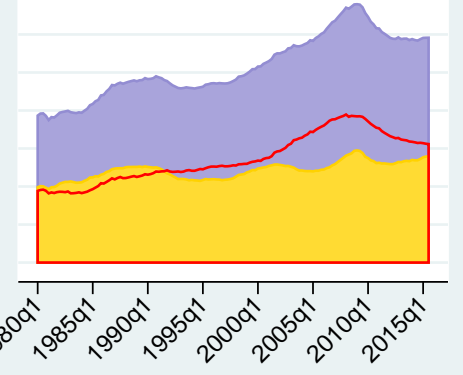

HNPd wrt GDP

In Figure 2 we report charts for the variables under analysis for each of the five countries considered.

The charts show that PNFd has grown along GDP in all the countries in the last decades; however, Italy exhibits a weaker co-movement, particularly with respect to HNPd. In all countries both debt variables are higher than GDP per-capita. As expected, the MMR dynamics is remarkably similar across countries and it is the same for the Euro Area countries since the Euro's introduction in 1999.

Table 1 shows correlation across countries and by country. Such correlations are very high: 0.91 for the PNFd aggregate, 0.78 for NFCd component, 0.86 for HNPd component. Interestingly, the correlation between NFCd and HNPd is much lower: $0.6353^{*}$. As for the country-by-country correlations, Italy exhibits the lowest correlation between PNFd and GDP, the United Kingdom exhibits the highest. The same holds with reference to NFCd and to HNPd. In the EA countries, the correlation between GDP and NFCd is higher than the correlation between GDP and HNPd. 
Figure 2: GDP, HNPd, NFCd
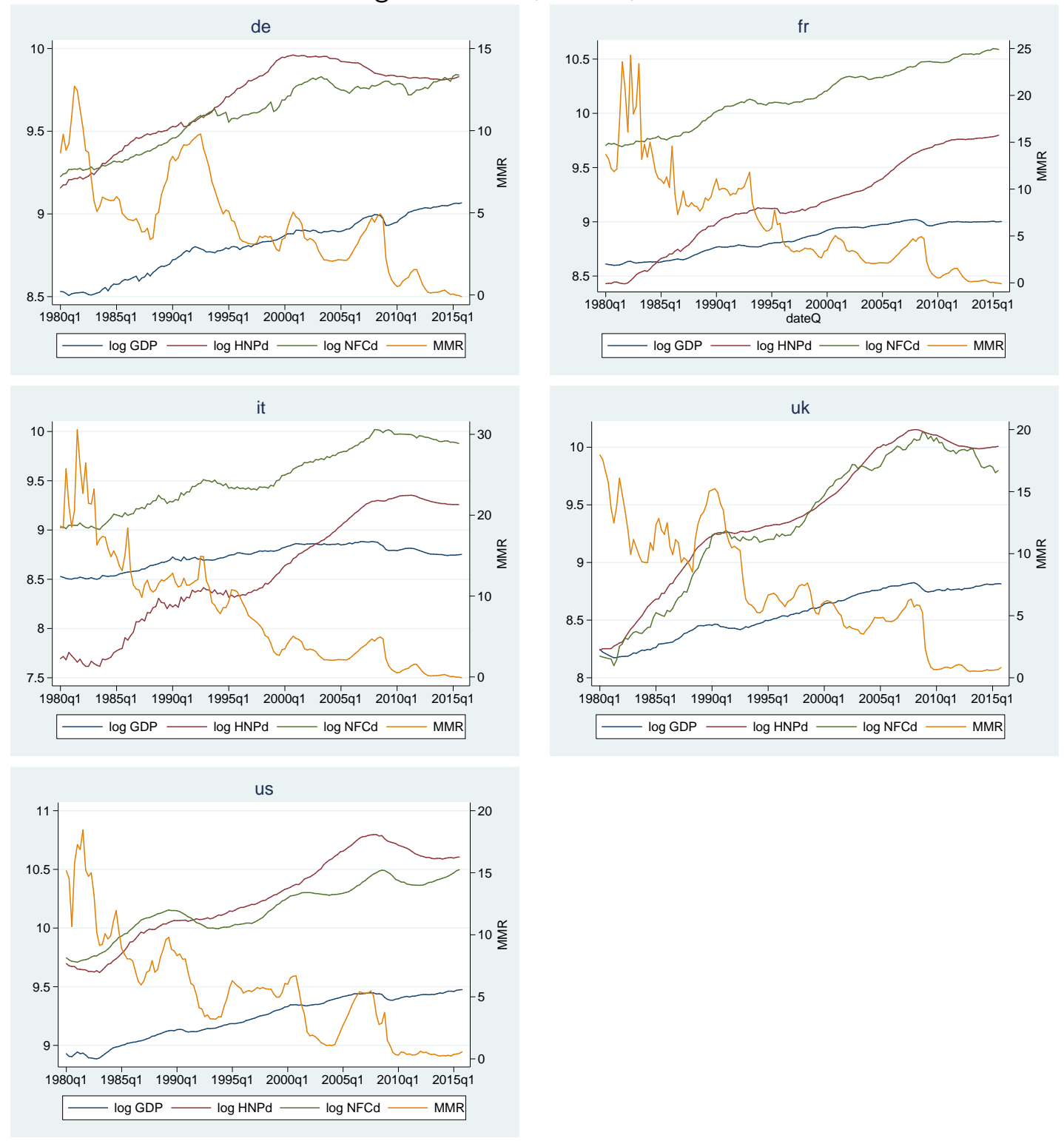

Notes: All variables are in real, per-capita terms. Logarithm transformation applied. 
Table 1: Pairwise Correlations

\begin{tabular}{|c|c|c|c|c|c|c|c|c|c|}
\hline \multicolumn{5}{|c|}{ Across Countries } & \multicolumn{5}{|l|}{ France } \\
\hline 715 obs & GDP & PNFd & $\mathrm{NFCd}$ & HNPd & 143obs & GDP & PNFd & NFCd & HNPd \\
\hline GDP & 1 & & & & GDP & 1 & & & \\
\hline PNFd & $0.9127^{*}$ & 1 & & & PNFd & $0.9528 *$ & 1 & & \\
\hline NFCd & $0.7823^{*}$ & $0.8784 *$ & 1 & & NFCd & $0.9635^{*}$ & $0.9974^{*}$ & 1 & \\
\hline HNPd & $0.8659^{*}$ & $0.9267^{*}$ & $0.6353^{*}$ & 1 & HNPd & $0.9196 *$ & $0.9915^{*}$ & $0.9799 *$ & 1 \\
\hline MMR & $-0.4959^{*}$ & $-0.6038^{*}$ & $-0.5667^{*}$ & $-0.5191^{*}$ & MMR & $-0.8621^{*}$ & $-0.8331^{*}$ & $-0.8394^{*}$ & $-0.8126^{*}$ \\
\hline \multicolumn{5}{|l|}{ Italy } & \multicolumn{5}{|c|}{ Germany } \\
\hline 143 obs & GDP & PNFd & NFCd & HNPd & 143 obs & GDP & PNFd & NFCd & HNPd \\
\hline GDP & 1 & & & & GDP & 1 & & & \\
\hline PNFd & $0.7964 *$ & 1 & & & PNFd & $0.9061^{*}$ & 1 & & \\
\hline NFCd & $0.7877^{*}$ & $0.9977^{*}$ & 1 & & $\mathrm{NFCd}$ & $0.9498 *$ & $0.9769^{*}$ & 1 & \\
\hline HNPd & $0.7384 *$ & $0.9925^{*}$ & $0.9910^{*}$ & 1 & HNPd & $0.8455^{*}$ & $0.9869 *$ & $0.9295^{*}$ & 1 \\
\hline MMR & $-0.8463^{*}$ & $-0.8587^{*}$ & $-0.8514^{*}$ & $-0.8355^{*}$ & MMR & $-0.7428 *$ & $-0.7186 *$ & $-0.7092 *$ & $-0.7042 *$ \\
\hline \multicolumn{5}{|c|}{ United Kingdom } & \multicolumn{5}{|c|}{ United States } \\
\hline 143 obs & GDP & PNFd & $\mathrm{NFCd}$ & HNPd & 143 obs & GDP & PNFd & NFCd & $\mathrm{HNPd}$ \\
\hline GDP & 1 & & & & GDP & 1 & & & \\
\hline PNFd & 0.9773* & 1 & & & PNFd & $0.9705^{*}$ & 1 & & \\
\hline NFCd & $0.9703^{*}$ & $0.9963 *$ & 1 & & NFCd & $0.9487^{*}$ & $0.9759 *$ & 1 & \\
\hline HNPd & $0.9767^{*}$ & $0.9967^{*}$ & $0.9862 *$ & 1 & HNPd & $0.9632 *$ & 0.9933* & $0.9441^{*}$ & 1 \\
\hline MMR & $-0.8485^{*}$ & $-0.8292 *$ & $-0.8243^{*}$ & $-0.8274 *$ & MMR & $-0.8300 *$ & $-0.7949 *$ & $-0.8022 *$ & $-0.7757^{*}$ \\
\hline
\end{tabular}

\section{Analysis}

When it comes to the relationship between GDP and debt, correlations do not say anything about the existence and direction of causality between them. ${ }^{9}$ As said, the effort to uncover the causal relationship between the two has been substantial and has resorted to different analytical approaches. Among the others, we have already highlighted Rajan \& Zingales (1998), Levine et al. (2000), Christopoulos \& Tsionas (2004), Kar et al. (2011) and Puente-Ajovín \& Sanso-Navarro (2015) for the diversity of the strategies adopted.

As said, this literature eventually assumes a direction of causality from private debt to GDP. We build on this result and check the effect of private debt on GDP in the short-run by considering its two components: Non-Financial Corporation debt (NFCd) and Households \& Non-Profit debt (HNPd). We

\footnotetext{
${ }^{9}$ This point is well discussed in Panizza \& Presbitero (2014), Panizza et al. (2013) with regard to public debt.
} 
consider as short-run a period of 6 quarters (one year and a half).

The analytical framework employed is a VAR with four variables: GDP, HNPd, NFCd, MMR. The VAR approach is particularly convenient for the scope of our analysis since it treats all the variables symmetrically and it is functional to compute impulse-response functions. Indeed, the objective is to compute impulse-response functions by country and compare them across countries to unveil differences about the effect of private debt on GDP. The inclusion of the MMR is to account for the financing conditions and how these influence the amount of debt.

First thing in order to fit the VAR is to check the stationarity of the variables involved in the analysis. Macroeconomic variables such as GDP, debt and market rates usually turn out to be not covariancestationary. As matter of fact, eyeballing the charts in Figure 2 suggests that all the variables have a clear trend. The variables might result to be stationary around a linear trend, but detrending does not make the series stationary. ${ }^{10}$ Then, the data are likely to be non-stationary around a stochastic trend. We have therefore run unit-root tests for all the variables. The hypotheses tested are: 1) "H0: unit root" using the DF-GLS test (Elliott et al. 1996), the ADF Test (Dickey \& Fuller 1979) and the PPerron test (Phillips \& Perron 1988); 2) "H0: no unit root" using the KPSS test (Kwiatkowski et al. 1992). Unit-root tests notoriously depend upon the inclusion of the deterministic components and they are sensitive to the number of lags included in the regression. ${ }^{11}$ We have run different alternatives, the results by country and by variable are reported in Table 4 and 5 in Appendix A. On the whole, the tests suggest that the variables are non-stationary and that a stochastic trend is present.

The presence of a stochastic trend in the variables affects directly the specification of the vector autoregression to use for the analysis. This is because of the theoretical possibility of cointegration among non-stationary variables (Engle \& Granger 1987), cointegration would involve the existence of a long-run relationship between GDP, HNPd and NFCd. This would be a fascinating occurrence to exploit in our analysis. Moreover, if a long-run relationship among such variables existed, a VAR which excludes it would be misspecified (Enders 2010). We have therefore checked the presence of cointegrating equations through the Johansen's approach (Johansen 1995). ${ }^{12}$ Based on its results, cointegrating equations are

\footnotetext{
${ }^{10}$ The standard procedure to check this is to run an OLS estimation of the variable on a linear trend, save the residuals and run unit-root tests on those residuals to check whether such a detrending procedure was enough to induce stationarity.

${ }^{11}$ Under the null of a unit root, inclusion of a constant in Dickey-Fuller kind of equations implies a linear trend, while under the alternative it is just a constant.

${ }^{12}$ These results are available upon request.
} 
not present among the variables under analysis. In the absence of cointegration, we estimate the VAR in first differences; we have verified that first differences make the data stationarity. The representation of the VAR estimated is the following:

$$
\left[\begin{array}{c}
\text { d.lHNPd } \\
\text { d.lNFCd } \\
\text { d.lGDPpc } \\
\text { d.MMR }
\end{array}\right]=\left[\begin{array}{c}
\alpha_{1} \\
\alpha_{2} \\
\alpha_{3} \\
\alpha_{4}
\end{array}\right]+\sum_{k=1}^{n} \Gamma_{k} \cdot\left[\begin{array}{c}
d . l H N P d_{t-k} \\
d . l N F C d_{t-k} \\
d . l G D P p c_{t-k} \\
d . l M M R_{t-k}
\end{array}\right]+\left[\begin{array}{c}
\epsilon_{1} \\
\epsilon_{2} \\
\epsilon_{3} \\
\epsilon_{4}
\end{array}\right] .
$$

The $\alpha$ coefficients are the deterministic terms in the VAR regressions, the elements in the $\Gamma$ matrices are the autoregressive coefficients. The variables were log-transformed before first-differencing, first differences therefore represent growth rates.

As known, it is crucial to specify correctly the VAR by including the appropriate number of lags in order to avoid auto-correlated residuals $\left(\epsilon_{t}\right)$. Standard methodologies suggest to start with the maximum reasonable number and to run Exclusion Tests of the highest lag-order included or, alternatively, to compare alternative lag-orders through information criteria (Lutkepohl 2005). We opt for the first approach. We start with an economically reasonable lag length, which is 6 (one year and a half dependence), and stop when the Wald test rejects the exclusion hypothesis and/or no auto-correlation emerges. The results of this procedure for each of the five countries considered are reported in Table 2. ${ }^{13}$ On the whole, the inclusion of five lags seems reasonable for all the countries considered.

Since all the equations in the VAR are symmetric, we perform a standard maximum-likelihood estimation country-by-country. The purpose of VAR estimations is not the checking of the single coefficients, but hypothesis testing on those coefficients and impulse-response analysis (Stock \& Watson 2001). Coherently, we report the estimation output in Appendix B for completeness, while we mention the results of the Granger-causality test and discuss the Impulse Response Functions in details in the next sub-section.

\footnotetext{
${ }^{13}$ The different Information Criteria provide very different suggestions with little economic meaning, this is why we opted for the first approach. More in details, we run subsequent Exclusion Tests and stop when the null is rejected. For that order, we check also that auto-correlation does not emerge. If auto-correlation emerges, we do not accept it as the number of lags to include in the VAR. In this case, we check auto-correlation at the 1-step higher order, if no auto-correlation emerges at that order, we include that number of lags in the VAR.
} 
Table 2: VAR Lag Selection

\begin{tabular}{|c|c|c|c|c|c|c|}
\hline & \multicolumn{2}{|l|}{ France } & \multicolumn{2}{|l|}{ Italy } & \multicolumn{2}{|l|}{ Germany } \\
\hline & $\mathrm{p}$-value $\left(\chi^{2}\right)$ & procedure & p-value $\left(\chi^{2}\right)$ & procedure & p-value $\left(\chi^{2}\right)$ & procedure \\
\hline Exclusion Test of 6 th lag & 0.141 & & 0.961 & & 0.346 & \\
\hline Exclusion Test of 5th lag & 0.001 & stop & 0.223 & & 0.006 & stop \\
\hline Exclusion Test of 4 th lag & & & 0.000 & stop & & \\
\hline$A C$ test at 5 th lag & 0.218 & ok & 0.408 & ok & 0.305 & ok \\
\hline AC test at 4 th lag & & & 0.000 & no ok & & \\
\hline \multirow[t]{3}{*}{ Final Selected: } & & 5 & & 5 & & 5 \\
\hline & \multicolumn{2}{|c|}{ United Kingdom } & \multicolumn{4}{|l|}{ United States } \\
\hline & p-value $\left(\chi^{2}\right)$ & procedure & p-value $\left(\chi^{2}\right)$ & procedure & & \\
\hline Exclusion Test of 6 th lag & 0.148 & & 0.432 & & & \\
\hline Exclusion Test of 5 th lag & 0.021 & stop & 0.000 & stop & & \\
\hline \multicolumn{7}{|l|}{ Exclusion Test of 4 th lag } \\
\hline AC test at 5 th lag & 0.052 & ok & 0.068 & ok & & \\
\hline \multicolumn{7}{|l|}{ AC test at 4 th lag } \\
\hline Final Selected: & & 5 & & 5 & & \\
\hline
\end{tabular}

Notes: - AC is the auto-correlation test, $\mathrm{H} 0$ "no auto-correlation" . The Exclusion test is the Wald test, HO "lag non-statistically different from zero".

\subsection{Inference on the Estimation Output}

On the whole, the results of the Granger-causality tests (Amisano \& Giannini 1997) raise doubts about the direction of causality between GDP and private debt. ${ }^{14}$ This is not surprising. In fact, doubts on their relationship have emerged also from previous contributions to this branch of literature (Ang 2008). Furthermore, the results of the tests are to take with caution since they are very sensitive to the number of lags included; even the short-run perspective taken might not be functional to test causality. This is why we do not focus on this point and consequently assume the consensus view in this literature: Causality from private debt to GDP (more recently, Arcand et al. 2015).

Orthogonalized Impulse Response Functions (OIRFs) are plotted in the following Figure 3 and 4. The ordering for the Cholesky decomposition is (1) MMR, (2) HNPd, (3) NFCd, (4) GDP. Since the underlying variables are growth rates (first difference of log variables), we preferred to plot Cumulative OIRFs; bootstrapped Confidence Intervals are reported in the Figures too. The values behind the plots are in Table 3.

\footnotetext{
${ }^{14}$ The results of the Granger causality test are in Table 6 in Appendix A. As for the relationship between GDP and HNPd/NFCd, GDP seems to be Granger-caused by NFCd only in France, and by HNPd only in Italy. Symmetrically, NFCd seems to be Granger-caused by GDP only in France; it is therefore mutual causality with GDP for France. HNPd seems never to be Granger-caused by GDP. Interestingly, for all countries but France, NFCd seems to be Granger-caused by HNPd; this is a result difficult to interpret, but useful for the identification of the shocks through the ordering for the Cholesky decomposition.
} 
Figure 3: Cumulative OIRFs: France, Italy, Germany

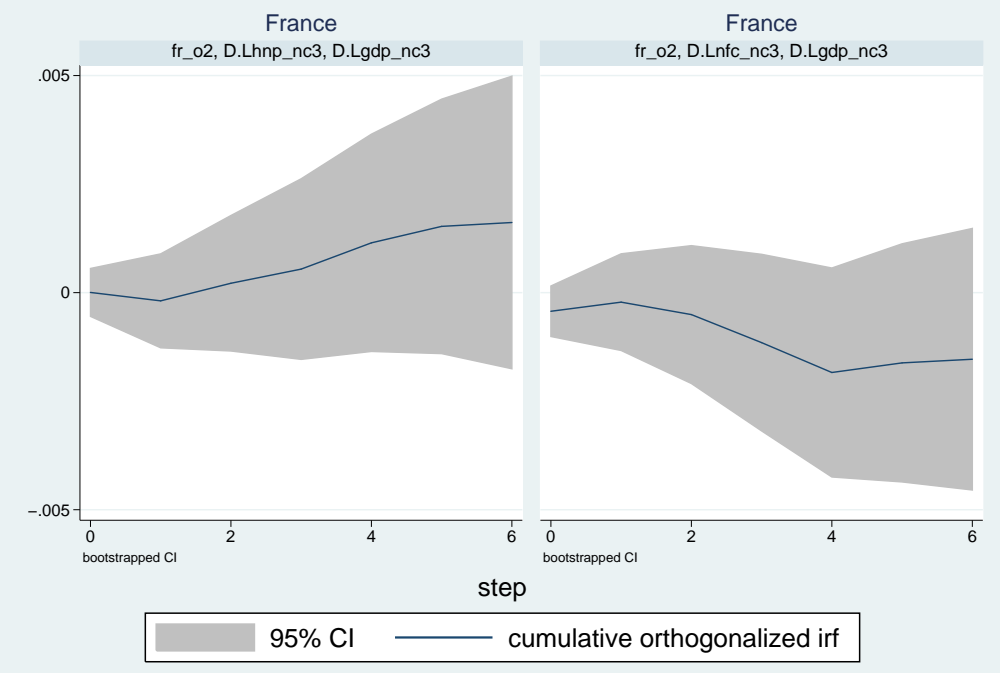

Graphs by irfname, impulse variable, and response variable

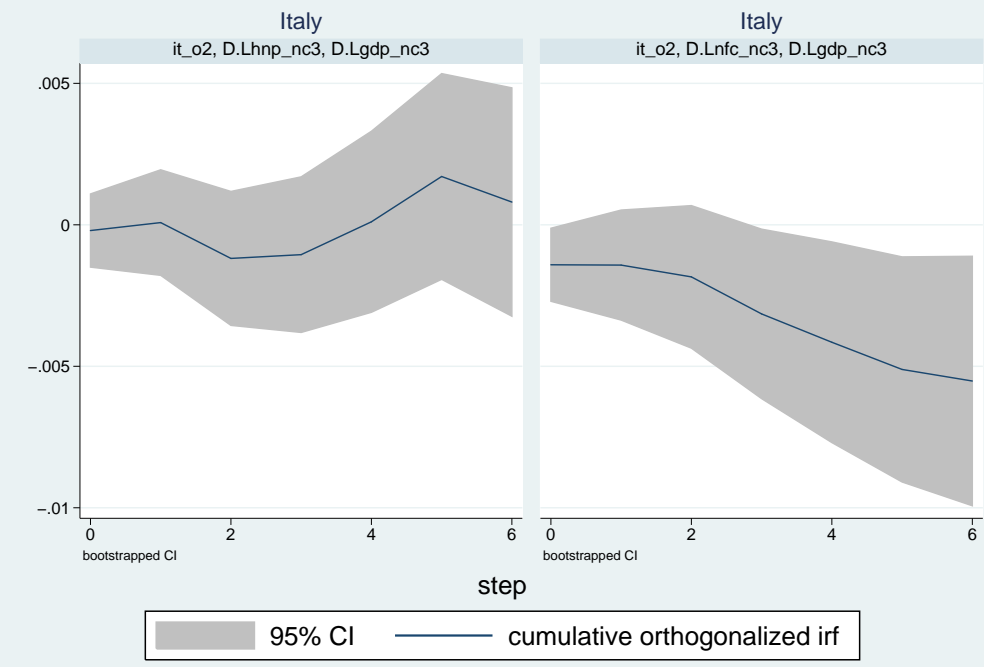

Graphs by irfname, impulse variable, and response variable

Germany

de o2, D.Lhnp_nc3, D.Lgdp_nc3

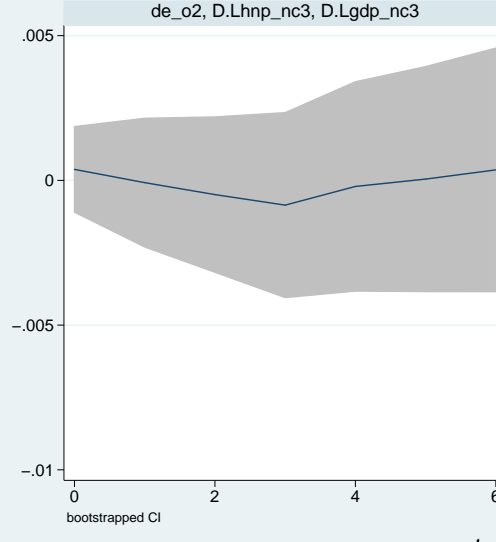$$
\begin{gathered}
1 \\
\text { bo }
\end{gathered}
$$

cumulative orthogonalized irf

Graphs by irfname, impulse variable, and response variable

Left chart: Impulse is D.IHNPd, Response is D.IGDP

Right chart: Impulse is D.INFCd, Response is D.IGDP 
Figure 4: Cumulative OIRFs: UK and USA

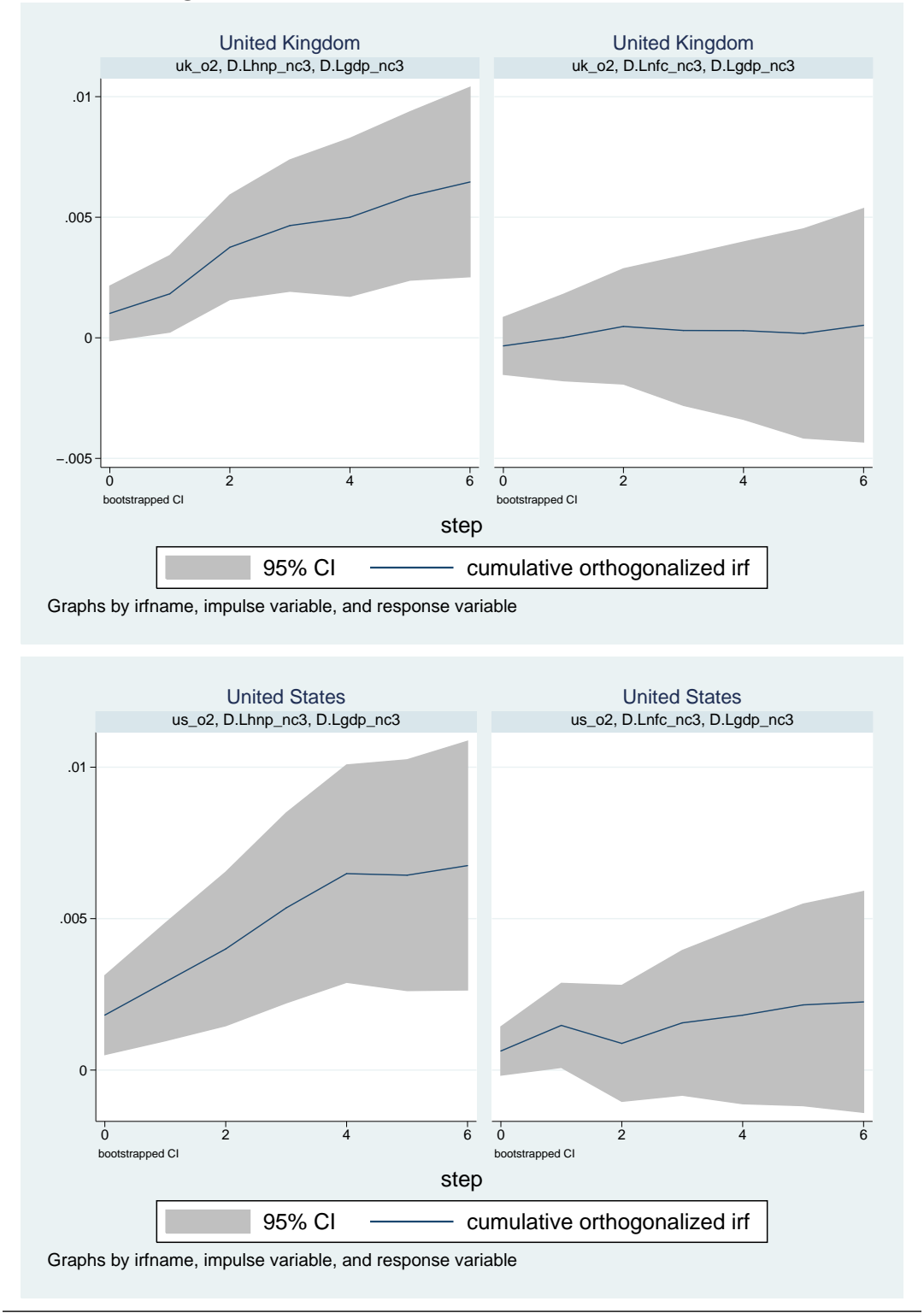

Left chart: Impulse is D.IHNPd, Response is D.IGDP

Right chart: Impulse is D.INFCd, Response is D.IGDP

Table 3: Cumulative Orthogonalized Impulse Response Functions

\begin{tabular}{l|ll|ll|ll|ll|rr}
\hline & France & & Italy & & \multicolumn{2}{l|}{ Germany } & \multicolumn{2}{l|}{ U.Kingdom } & U.States \\
\hline step & 1 & 2 & 1 & 2 & 1 & 2 & 1 & 2 & 2 \\
\hline 0 & $4.80 \mathrm{E}-06$ & -0.00043 & -0.0002 & -0.00141 & 0.00038 & -0.00085 & 0.001013 & -0.00033 & 0.001816 & 0.000631 \\
1 & -0.00019 & -0.00022 & 0.00008 & -0.00142 & $-7.8 \mathrm{E}-05$ & -0.00016 & 0.001824 & 0.000012 & 0.002909 & 0.001475 \\
2 & 0.000216 & -0.00051 & -0.00119 & -0.00184 & -0.00049 & -0.00119 & 0.003755 & 0.000473 & 0.004 & 0.000881 \\
3 & 0.000543 & -0.00115 & -0.00105 & -0.00315 & -0.00086 & -0.00121 & 0.004654 & 0.000304 & 0.005354 & 0.001559 \\
4 & 0.001148 & -0.00184 & 0.000107 & -0.00415 & -0.00021 & -0.0005 & 0.004997 & 0.000298 & 0.006487 & 0.001812 \\
5 & 0.001526 & -0.00162 & 0.001709 & -0.00511 & 0.000044 & -0.00171 & 0.005882 & 0.000182 & 0.006435 & 0.002153 \\
6 & 0.001616 & -0.00153 & 0.000806 & -0.00552 & 0.000363 & -0.00249 & 0.006461 & 0.00052 & 0.006751 & 0.00225 \\
\hline
\end{tabular}

1- Impulse: D.IHNPd, Response: D.IGDP | 2- Impulse: D.INFCd, Response: D.IGDP 


\section{Effect of Households \& Non-Profit debt on GDP}

As for the effect of per-capita HNPd on per-capita GDP growth, the impact effect is positive for Germany, the UK and the USA, it is negative for Italy, and it does not seem different from zero for France. The cumulative effect is definitely positive for the United Kingdom and the United States; it is very much comparable for these two countries. It is positive for France too, but confidence-intervals are wide and include zero. Italy and Germany exhibit a close-to-zero effect. In terms of evolution, after the impact, the effect is constantly positive for the United Kingdom and the United States. France exhibits a negative variation only after one quarter but the effect becomes constantly positive afterwards. Germany exhibits a slightly U-shaped effect with a minimum at the third quarter. Italy exhibits a very variable effect which is negative for many quarters.

\section{Effect of Non-Financial Corporations Debt on GDP}

As for the effect of per-capita NFCd on per-capita GDP growth, the results are much different compared to HNPd. The impact effect is negative for France, Italy and Germany, close to zero for the UK, markedly positive for the USA. The cumulative effect seems quite positive only for the United States, while it does not seem significantly different from zero for the United Kingdom. It is definitely negative for France, Italy and Germany. In terms of evolution, there is more volatility in France, Germany and the USA. The evolution is smoother for Italy and the United Kingdom; the latter exhibits a particularly flat effect.

\subsection{Discussion of the results}

On the whole, HNPd has a positive short-run effect on GDP. Differently, NFCd has a negative short-run effect on GDP growth in France, Italy and Germany. Let us discuss first the case when the cumulative effect is positive both for HNPd and NFCd; based on our results, this is definitely the case of the USA.

Since we are considering the short-run effect on GDP growth, it makes sense that HNPd has a larger impact on economic activity in the short-run. This is easier to understand if we assume that households borrow for consumption, while firms borrow to invest in medium-to-long term projects. The latter are likely to need more time to cause consumption of investment goods to rise. 
But, how to explain a negative effect of NFCd in France, Italy and Germany? This might depend upon the uncertain causality direction. Puente-Ajovín \& Sanso-Navarro (2015) show that causality is much clearer from HNPd to GDP than from NFCd to GDP. If we think about this, as matter of fact, we do not know for which reason firms really borrow. Positive shocks might be associated with a negative GDP evolution during certain periods because firms borrow from banks to meet their financial needs during those unfortunate periods. Interestingly, the negative effect emerges in those countries where firms, also because of their smaller average size, are more likely to depend upon the banking channel than firms in the United Kingdom and the United States (EIB 2014, 2013).

\section{Conclusions}

Private debt has been considered an important determinant of economic growth for many years. The literature assuming and quantifying the causal effect of private debt, meant as the financial-depth of the economy, on GDP over the long-run is large and rewarded with majority consensus.

Our research departs from that literature in three important aspects. First and foremost, we have focused on the short-run effect of private debt on economic activity. This is because our interest is in understanding whether an increase of private debt has stimulated economic activity quickly in the past. Indeed, if this is the case, policy measures which ease lending might be effective to contrast an economic downturn. Secondly, we have differentiated between debt granted to households \& non-profit institutions from debt granted to non-financial corporations. Thirdly, we have opted for a countryby-country analysis in order to unveil differences across countries which are likely to have a different background with regard to households and corporate financing.

On the whole, our results suggest that households \& non-profit debt has been effective as a stimulus to economic activity in the short-run. On the contrary, the evidence is mainly negative with respect to non-financial corporations debt in all countries but the USA. This may be explained by considering the potentially different motivations behind households and corporate indebtedness (section 3.2). Based on our results, policy measures aimed to a quick recovery of economic activity should favor households borrowing. 


\section{References}

Amisano, G. \& Giannini, C. (1997), Topics in Structural VAR econometrics, Springer. 10

Ang, J. B. (2008), 'A survey of recent developments in the literature of finance and growth', Journal of economic Surveys 22(3), 536-576. 1, 10

Arcand, J. L., Berkes, E. \& Panizza, U. (2015), 'Too much finance?', Journal of Economic Growth 20(2), 105-148. 1, 10

Arestis, P., Demetriades, P. O. \& Luintel, K. B. (2001), 'Financial development and economic growth: the role of stock markets', Journal of money, credit and banking pp. 16-41. 2

Blanchard, O., DellAriccia, G. \& Mauro, P. (2010), 'Rethinking macroeconomic policy', Journal of Money, Credit and Banking 42, 199-215. 2

Cecchetti, S., Mohanty, M. \& Zampolli, F. (2011a), Achieving growth amid fiscal imbalances: the real effects of debt, in 'Economic Symposium Conference Proceedings. Federal Reserve Bank of Kansas City', pp. 145-196. 2

Cecchetti, S., Mohanty, M. \& Zampolli, F. (2011b), The real effects of debt, Working Paper 352, BIS. 2

Christopoulos, D. K. \& Tsionas, E. G. (2004), 'Financial development and economic growth: evidence from panel unit root and cointegration tests', Journal of development Economics 73(1), 55-74. 1, 7

Cloyne, J., Ferreira, C. \& Surico, P. (2016), Monetary policy when households have debt: new evidence on the transmission mechanism, Staff Working Paper 589, Bank of England. 2

Dickey, D. A. \& Fuller, W. A. (1979), 'Distribution of the estimators for autoregressive time series with a unit root', Journal of the American statistical association 74(366a), 427-431. 8

Eberhardt, M. \& Presbitero, A. F. (2015), 'Public debt and growth: Heterogeneity and non-linearity', Journal of International Economics 97(1), 45-58. 1

ECB (2011), The monetary policy of the ECB, 3rd edn, European Central Bank. 2

EIB (2013), Investment and Investment Finance in Europe, Technical report, European Investment Bank. 14

EIB (2014), Unlocking lending in Europe, Technical report, European Investment Bank. 14

Elliott, G., Rothenberg, T. J. \& Stock, J. H. (1996), 'Efficient tests for an autoregressive unit root', Econometrica: Journal of the Econometric Society pp. 813-836. 8

Enders, W. (2010), Applied econometric time series, 3rd edn, John Wiley \& Sons. 8

Engle, R. F. \& Granger, C. W. (1987), 'Co-integration and error correction: representation, estimation, and testing', Econometrica: journal of the Econometric Society pp. 251-276. 8

Estevadeordal, A. \& Taylor, A. M. (2013), 'Is the Washington Consensus dead? Growth, openness, and the great liberalization, 1970s-2000s', Review of Economics and Statistics 95(5), 1669-1690. 2

IMF (2012), The Liberalization and Management of Capital Flows: an Institutional View, International Monetary Fund. 2

Johansen, S. (1995), Likelihood-based inference in cointegrated vector autoregressive models, Oxford University Press on Demand. 8

Jordà, Ò., Schularick, M. \& Taylor, A. M. (2015), 'Sovereigns versus Banks: Credit, Crises, and Consequences', Journal of the European Economic Association . 1

Jordà, Ò., Schularick, M., Taylor, A. M. et al. (2014), 'Private credit and public debt in financial crises'. 1

Kar, M., Nazlıŏlu, Ș. \& Ağır, H. (2011), 'Financial development and economic growth nexus in the MENA countries: Bootstrap panel granger causality analysis', Economic Modelling 28(1), 685-693. 1,7 
Kwiatkowski, D., Phillips, P. C., Schmidt, P. \& Shin, Y. (1992), 'Testing the null hypothesis of stationarity against the alternative of a unit root: How sure are we that economic time series have a unit root?', Journal of econometrics 54(1), 159-178. 8

Levine, R. (2005), 'Finance and growth: theory and evidence', Handbook of economic growth 1, 865934. i, 1

Levine, R., Loayza, N. \& Beck, T. (2000), 'Financial intermediation and growth: Causality and causes', Journal of monetary Economics 46(1), 31-77. 1, 7

Lof, M. \& Malinen, T. (2014), 'Does sovereign debt weaken economic growth? A panel VAR analysis', Economics Letters 122(3), 403-407. 3

Lutkepohl, H. (2005), New Introduction to Multiple Time Series Analysis, Springer. 9

Mishkin, F. S. (2011), Monetary policy strategy: lessons from the crisis, Technical Report 16755, National Bureau of Economic Research. 2

Panizza, U. \& Presbitero, A. F. (2014), 'Public debt and economic growth: is there a causal effect?', Journal of Macroeconomics 41, 21-41. 7

Panizza, U., Presbitero, A. F. et al. (2013), 'Public debt and economic growth in advanced economies: A survey', Swiss Journal of Economics and Statistics 149(2), 175-204. 7

Papademos, L. (2003), The contribution of monetary policy to economic growth. 2

Phillips, P. C. \& Perron, P. (1988), 'Testing for a unit root in time series regression', Biometrika 75(2), 335-346. 8

Puente-Ajovín, M. \& Sanso-Navarro, M. (2015), 'Granger causality between debt and growth: Evidence from OECD countries', International Review of Economics \& Finance 35, 66-77. 1, 2, 7, 14

Rajan, R. G. \& Zingales, L. (1998), 'Financial Dependence and Growth', The American Economic Review 88(3), 559-586. 1, 7

Rodrik, D. (2006), 'Goodbye Washington consensus, hello Washington confusion? A review of the World Bank's economic growth in the 1990s: learning from a decade of reform', Journal of Economic literature 44(4), 973-987. 2

Stock, J. H. \& Watson, M. W. (2001), 'Vector Autoregressions', The Journal of Economic Perspectives 15(4), 101-115. 9

Sufi, A. (2015), Out of Many, One? Household Debt, Redistribution and Monetary Policy during the Economic Slump, in 'Andrew Crockett Memorial Lecture'. 3 


\section{Appendix A. Tables and Figures}

Table 4: Unit-Root tests - GDP, HNPd

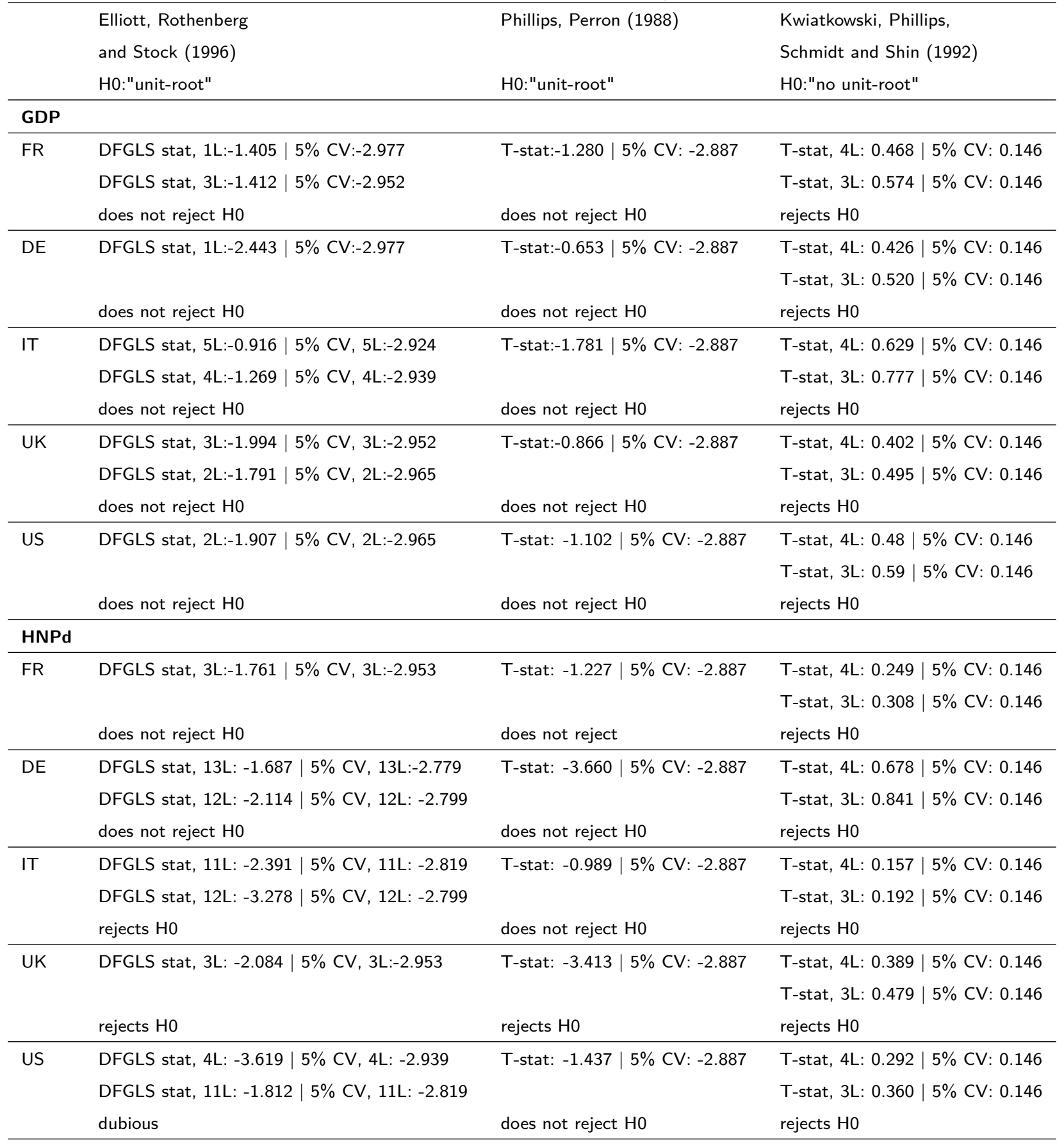


Table 5: Unit Root tests - NFCd, MMR

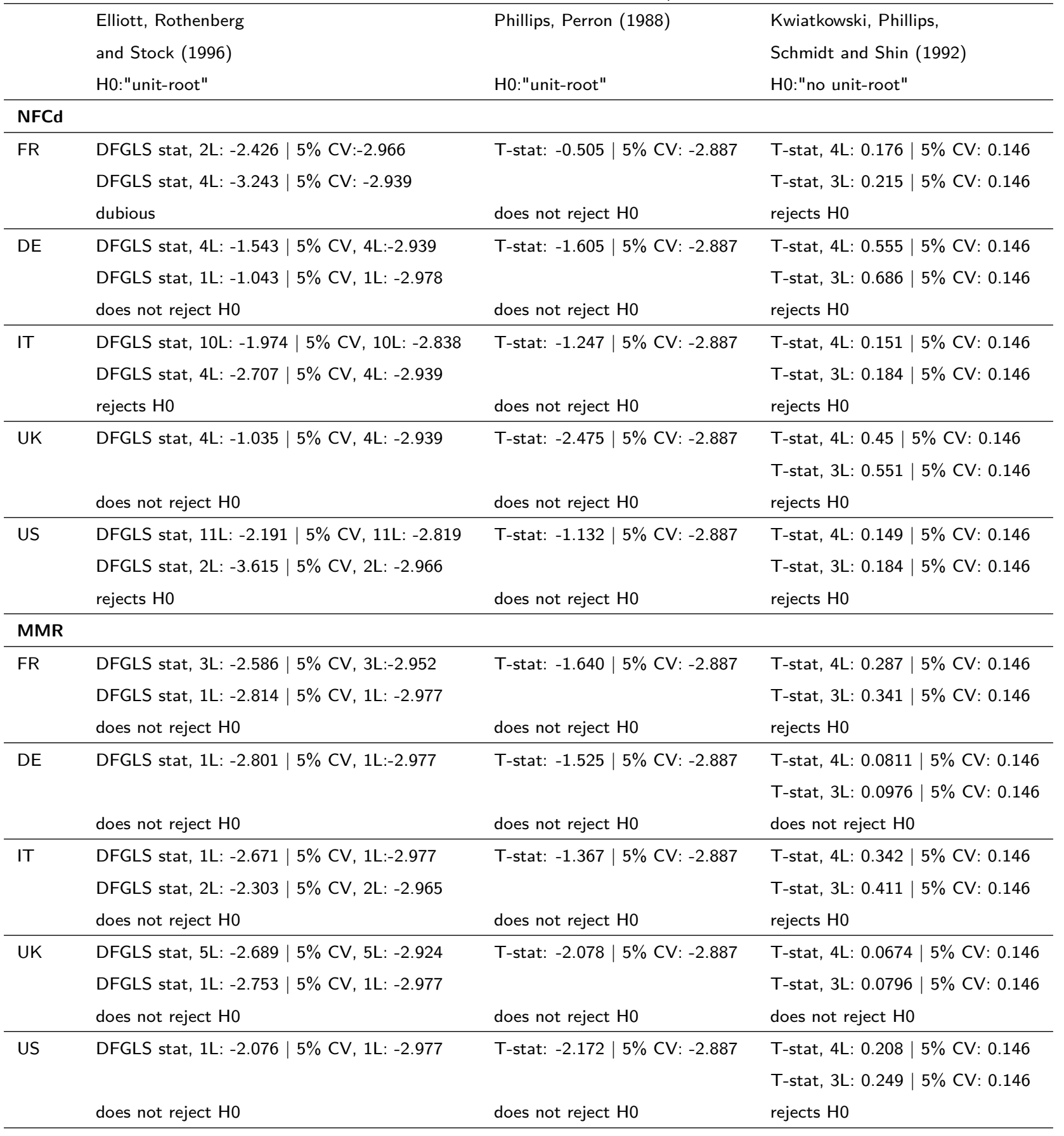


Table 6: Granger-causality tests

\begin{tabular}{lll|l|l|l|l|l}
\hline & & & FR & IT & DE & UK & US \\
\hline y & x & df & p-value $\left(\chi^{2}\right)$ & p-value $\left(\chi^{2}\right)$ & p-value $\left(\chi^{2}\right)$ & p-value $\left(\chi^{2}\right)$ & p-value $\left(\chi^{2}\right)$ \\
\hline D.IGDP & D.MMR & 5 & 0.042 & 0.133 & 0.390 & 0.348 & 0.544 \\
D.IGDP & D.IHNPd & 5 & 0.489 & 0.017 & 0.576 & 0.056 & 0.297 \\
D.IGDP & D.INFCd & 5 & 0.027 & 0.387 & 0.100 & 0.874 & 0.102 \\
D.IGDP & ALL & 15 & 0.010 & 0.001 & 0.213 & 0.074 & 0.031 \\
\hline D.IHNPd & D.MMR & 5 & 0.119 & 0.055 & 0.089 & 0.000 & 0.438 \\
D.IHNPd & D.INFCd & 5 & 0.143 & 0.416 & 0.889 & 0.210 & 0.204 \\
D.IHNPd & D.IGDP & 5 & 0.117 & 0.811 & 0.727 & 0.187 & 0.586 \\
D.IHNPd & ALL & 15 & 0.078 & 0.218 & 0.434 & 0.001 & 0.328 \\
\hline D.INFCd & D.MMR & 5 & 0.749 & 0.443 & 0.646 & 0.544 & 0.768 \\
D.INFCd & D.IHNPd & 5 & 0.451 & 0.006 & 0.003 & 0.008 & 0.000 \\
D.INFCd & D.IGDP & 5 & 0.000 & 0.445 & 0.319 & 0.815 & 0.099 \\
D.INFCd & ALL & 15 & 0.000 & 0.012 & 0.020 & 0.077 & 0.000 \\
\hline D.MMR & D.IHNPd & 5 & 0.510 & 0.026 & 0.137 & 0.504 & 0.023 \\
D.MMR & D.INFCd & 5 & 0.031 & 0.335 & 0.707 & 0.501 & 0.056 \\
D.MMR & D.IGDP & 5 & 0.006 & 0.012 & 0.000 & 0.381 & 0.000 \\
D.MMR & ALL & 15 & 0.002 & 0.005 & 0.000 & 0.378 & 0.000 \\
\hline Notes: .H0 & D d & & & & &
\end{tabular}

Notes: $\cdot H 0 " x$ does not Granger-cause y". Blue-colored values signal rejection of H0, then where Granger-causality emerges.

\section{Appendix B. VAR estimation output}



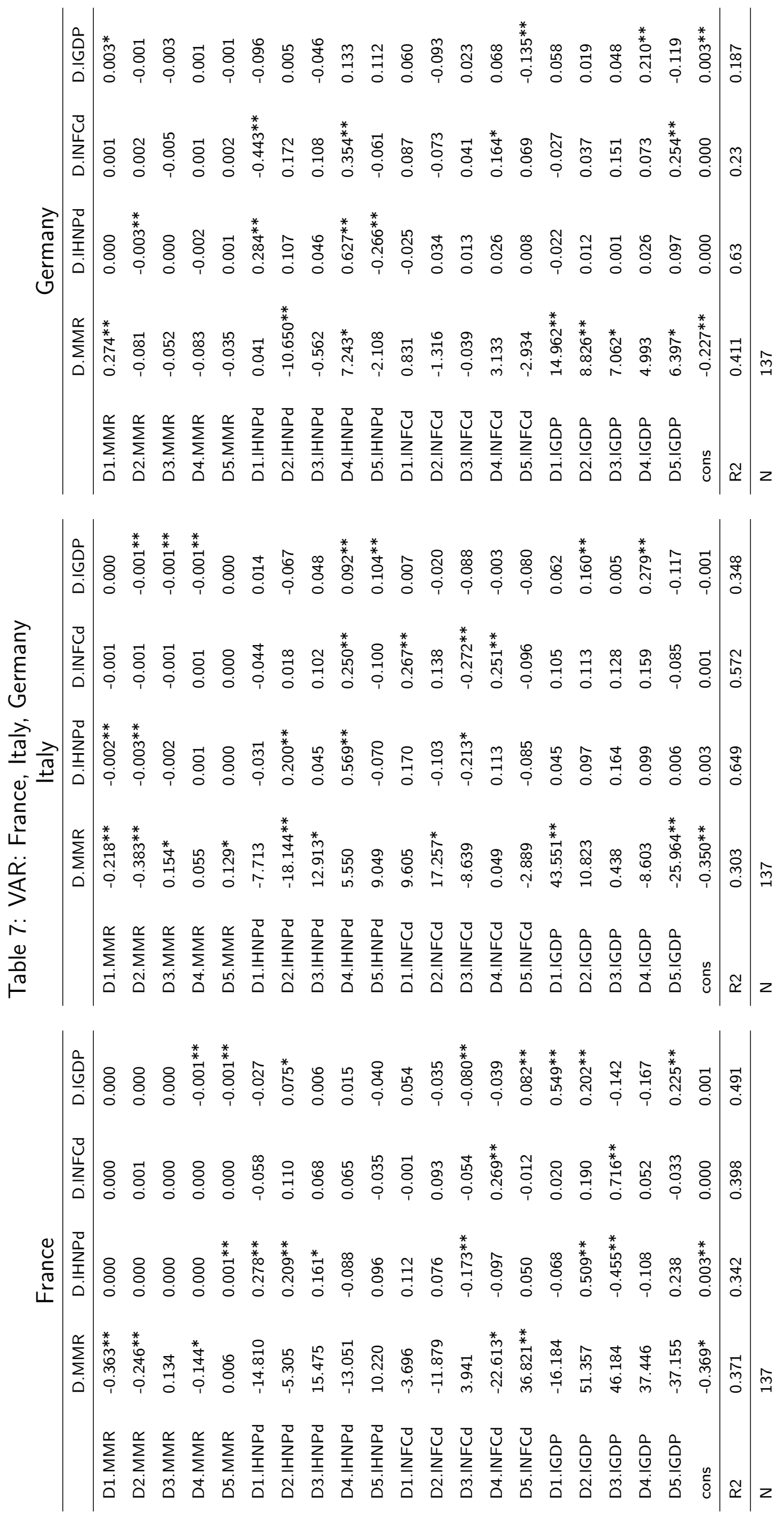


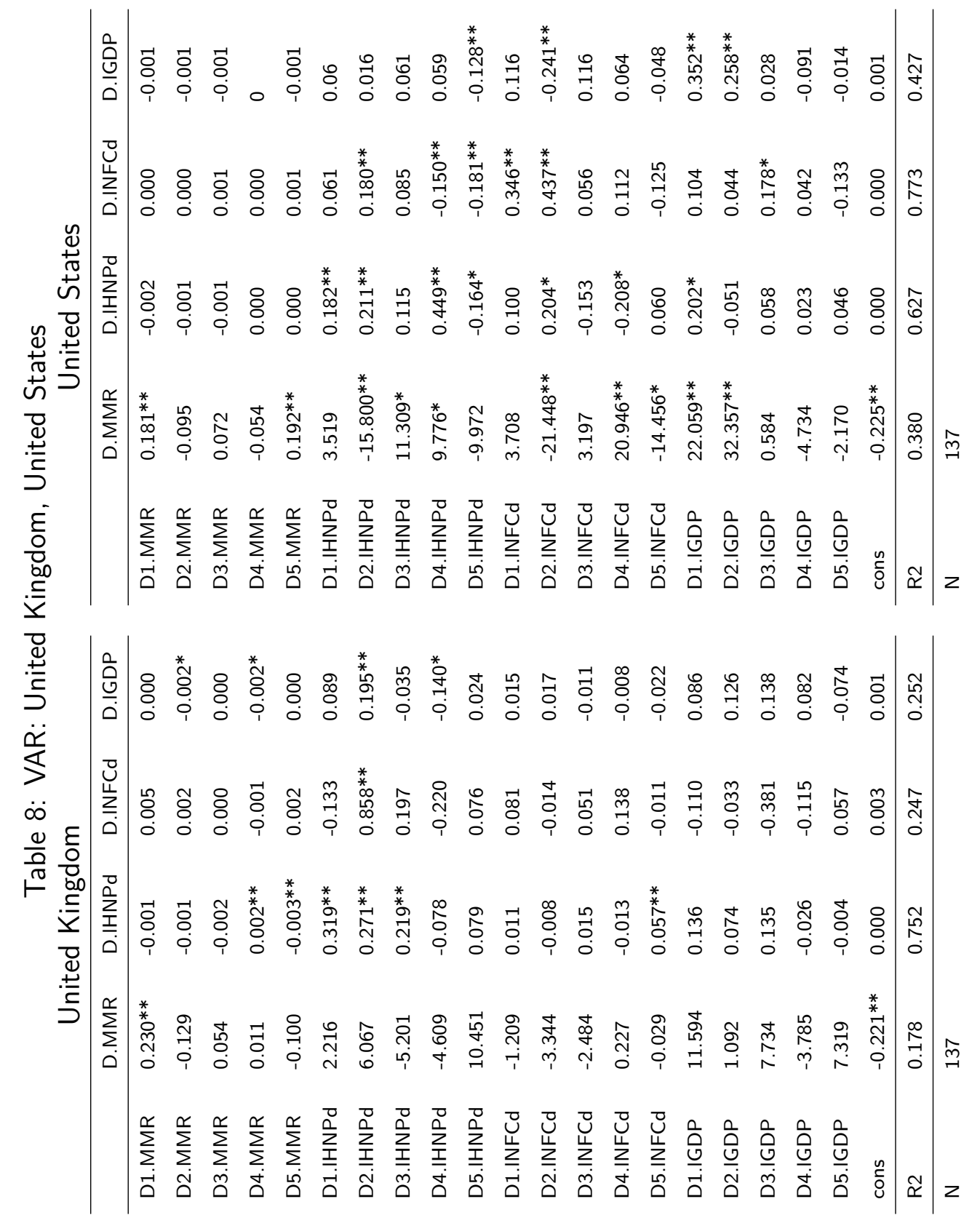

